\title{
The Economics of a Four-Day School Week: Community and Business Leaders' Perspectives
}

\author{
Jon Scott Turner ${ }^{1}$, Kim Finch ${ }^{1}$, Ximena Uribe-Zarain ${ }^{1}$ \\ ${ }^{1}$ Department of Counseling, Leadership, and Special Education, Missouri State University, Springfield, USA \\ Correspondence: Jon Scott Turner, Counseling, Leadership and Special Education, Missouri State University, \\ Springfield, MO., 65897, USA.
}

Received: January 23, 2018

Accepted: February 15, 2018

Available online: February 27, 2018

doi:10.11114/aef.v5i2.2947

URL: https://doi.org/10.11114/aef.v5i2.2947

\begin{abstract}
The four-day school week is a concept that has been utilized in rural schools in the United States for decades and the number of schools moving to the four-day school week is growing. In many rural communities, the school district is the largest regional employer which provides a region with permanent, high paying jobs that support the local economy. This study collects data from 71 community and business leaders in three rural school districts that have transitioned to the four-day school week within the last year. Quantitative statistical analysis is used to investigate the perceptions of community and business leaders related to the economic impact upon their businesses and the community and the impact the four-day school week has had upon perception of quality of the school district. Significant differences were identified between community/business leaders that currently have no children in school as compared to community/business leaders with children currently enrolled in four-day school week schools. Overall, community/business leaders were evenly divided concerning the economic impact on their businesses and the community. Community/business leaders' perceptions of the impact the four-day school week was also evenly divided concerning the impact on the quality of the school district. Slightly more negative opinions were identified related to the economic impact on the profitability of their personal businesses which may impact considerations by school leaders. Overall, community/business leaders were evenly divided when asked if they would prefer their school district return to the traditional five-day week school calendar.
\end{abstract}

Keywords: four-day, school week, school calendar, economics of education, education policy

\section{Introducation}

\subsection{Introduce the Problem}

Rural school districts are often the economic engine that drives local communities (Sederberg, 1987; Woods, Doeksen, \& St. Clair, 2005). School districts provide isolated, rural communities with a relatively large number of stable jobs that are amongst the highest paid job opportunities in a region. In 2014, approximately 15 percent of United States residents resided in rural counties, the lowest percentage in American history with net outmigration outpacing natural increases in rural counties (Kusmin, 2015). Facing these demographic trends, more than ever, rural areas of the United States need the economic benefits provided by local school districts which provide the purchasing power of payrolls, employment opportunities, revenue, and customers for local businesses.

The concept of a compressed work week or 4 day-40 hour work schedule is common in some areas of business and government in the United States; working fewer days with longer work hours has been studied for many years in business and administrative research (Baltes, Huff, Wright \& Newman, 1999; Cunningham, 1982; Facer \& Wadsworth, 2010; Hodge \& Tellier, 1975). United States federal law allows federal agencies to institute compressed work schedules for federal employees (Flexible and Compressed Work Schedules, 1982). More and more, school districts in the rural United States are looking to alternative school schedules that are very similar to these compressed work week schedules in order to meet challenges in their schools.

In the United States, the general trend regarding school year length has been to increase the number of school days required during a school year or to replace the school days-per-year requirement with a hours-per-year requirement (DeNisco, 2013; Woods et al., 2005). The option to move to a school calendar based on hours-per-year opened alternatives for schools to reduce the number of school days by shifting to four-day school weeks. In 2011, a survey 
completed by the Washington Post found that at least 292 school districts in the United States use the four-day school week, more than double the number estimated two years earlier (Layton, 2011). In 2017, fifty percent of the school districts in the state of Colorado were using the four-day school week (French, 2017). Most of the existing research on the four-day school week has been conducted by state departments of education or individual school districts. "Though over 100 districts across the country operate on a four-day week, there is a lack of peer-reviewed research on the topic" (Plucker, Cierniak, \& Chamberlin, 2012, p. 5). While compressed work weeks have been extensively studied within the corporate world, research from the school based settings are sparse and research related to the impact of a four-day school week on the local economy is almost non-existent.

\subsection{Four-Day Work Week: A Cost-Saving Initiative}

The move to a four-day school week is often driven by the need to save money during state or school district budget constraints (Anderson \& Walker, 2015; Bitton, 2016; Cummings, 2015; Donis-Keller \& Silvernail, 2009; Henton, 2015; Herring, 2010; Juneau, 2011; Plucker et al., 2012; Sagness \& Salzman, 1993; Tobias, 2016). This budget driven innovation in schools is identical to the actions taken by governmental agencies that face funding constraints that result in changes to worker schedules. In 2008, Utah Governor Jon Huntsman announced that his state would implement a mandatory four-day work week for most state workers. At the time of the announcement, Huntsman said the shift in schedule would allow the state to deal with rising energy costs and recruit and retain high quality employees (Facer \& Wadsworth, 2010).

The move to a four-day school week during hard financial times is not new in the United States; a shortened school week was used during the Great Depression of the 1930's in hard-hit communities (Donis-Keller \& Silvernail, 2009). In the 1970 's, the United States gained a renewed interest in reducing the number of school days due to increased heating and transportation costs during the 1973 Arab oil embargo (Cummings, 2015). In 2009, while facing a budget crisis, Hawaii officials implemented seventeen mandatory "Furlough Fridays" for state public schools, implementing a temporary four-day school week statewide (Herring, 2010).

While cost savings is often given as at least one justification for schools moving to the four-day school week, a study completed by the nonpartisan Education Commission of the States determined the maximum financial savings experienced by school districts around the country implementing the four-day school week was just over five percent (Griffith, 2011). Savings has typically been less for those districts making the switch to a shortened school week (Rosenberg, 2015). Some research findings point to public opposition to the four-day school week to save money (Ray, 2003); however, new reasons beyond money savings are now given by school leaders for a shift to longer but fewer school days in American schools (Dam, 2006; DenOuden, 2016).

\subsection{Four-Day School Week in the Rural Economy}

In the United States, the move toward four-day school weeks has been driven mainly in small, rural, and isolated school districts (Richert, 2016). The mountain west states have seen a proliferation of four-day school districts; for example, in Idaho over 9\% of the student population attend schools with four-day weeks (Richert, 2016) and 42 of the Idaho's 115 public school districts now follow a four-day a week school calendar (Cummings, 2015).

Rural school districts in many states have struggled to keep and attract teachers (Ayala, 2017; Leal, 2017). While historically cost savings have primarily been given as the driving factor in the move toward four-day school weeks, more and more the ability to attract and retain teachers (Cooley, 2017; DeNisco, 2013; Hinton, 2017; Stotts, 2017), increase student and staff attendance rates, and to provide additional time for professional development (Morones, 2013) are given by rural school leaders as the reason for the change. It is unknown what economic impact will be experienced in rural communities when schools are only open four days a week. The extra day with no school can greatly reduce traffic into communities where rural schools are located and can potentially give parents more opportunities to travel distances to shop in larger communities with their children being out of school an additional day.

In 2009, the state of Missouri enacted legislation giving school districts an option of retaining a five-day school week with a minimum of 174 days or transitioning to a four-day school week with a minimum of 142 days and a minimum of 1044 hours of instruction (Missouri Department of Elementary and Secondary Education, 2013; Rowland, 2014; School Operations, 2009). This change gave Missouri school districts the flexibility to choose the school day calendar that best fit the local context. During the 2017-2018 school year, 25 of Missouri's 518 public school districts have implemented the four-day school week (Missouri Department of Elementary and Secondary Education, 2018). Since the option was made available in the state, only one school district returned to a traditional five-day school week (Levin, 2016). The one school district that did return to the five-day school week cited the increase in school day length and the perceived negative impact longer instructional days had on elementary grade children (Newman, Pavolva, \& Luna, 2016) as the reason for reconsideration.

A majority of school districts within Missouri have a K-12 enrollment of less than 800 students, with over 100 of the 518 
school districts having less than 200 students in grades K-12. During the 2016-2017 school year, the average K-12 student enrollment of school districts using the four-day calendar was 464 students with only three school districts having a K-12 enrollment of more than 900 students. This small school culture in the state of Missouri means that most small communities still retain their local school buildings, even in very small villages. This is very different than in the western states where four-day school weeks are common. The extremely rural and isolated nature of many geographically large school districts in western states adds to the cost of transportation of students over a large number of miles; travel distances are less in the geographically smaller school districts of Missouri. In western states it is common for rural consumers to drive many miles to purchase goods; in Missouri, almost all school districts are within 30 miles of a community with a significant commercial shopping district which are often outside the school district.

The economic impact of rural school districts upon the regional economy in rural areas is significant (Lyson, 2002). Economists from the U. S. Forestry Service estimate that for every 100 elementary and secondary school jobs created in rural schools, 56 additional jobs are created in a region due to business sales and household spending (Woods et al., 2005). Woods et al., (2005) found that in one rural Oklahoma county, the $\$ 9.3$ million payroll of the school districts resulted in a secondary payroll increase in the county of an additional $\$ 6.2$ million. One important area of research, related to the implementation of the four-day school week, that has not been investigated is the economic impact on the community and the perceptions of current community and business leaders.

\section{Method}

\subsection{Methods}

An overall list of community/business leaders was provided by each of the three small rural school districts to the researchers based on tax records. A separated list of local elected officials was also created by the research team. All community/business leaders on the lists were mailed the survey instrument with a return envelope to the researcher provided. All three school districts participating have very small business districts within their communities, with two of the school districts having less than 15 businesses in their communities. A total of 71 community and business leaders responded to the four-day school week perception survey within the school districts that participated in the study. The overall return rate of surveys distributed was $59 \%$.

\subsection{Participant (Subject) Characteristics}

Ninety-three percent of the community/business leaders responding operated a business in the school district that had just completed the first year on a four-day school week. Thirty-seven percent of the community/business member respondents had children enrolled in school at the time of the survey, and $28 \%$ of the community or business leaders attended the school district where they owned a business at some point in their lives. Twenty-seven percent of the businesses represented were retail sales, $14 \%$ food service, $11 \%$ government related, and the rest were divided among agriculture, construction, and other types of business. Nine respondents (12.7\%) were elected officials within their community.

\section{Results}

Overall, community/business leaders exhibited two types of distribution of opinions, either the responses were evenly distributed among agreeing, being neutral, and disagreeing or they had strong opinions and were divided among agreeing and disagreeing with the items on the survey. First, they were asked questions related to the impact the four-day week school model had had on their businesses. The second part of the survey was about their perception on how the four-day week model affected the school and students. The researchers hypothesized that the perception of community/business leaders would vary depending on whether they had children enrolled in the district that recently switched to the four-day school calendar model.

In this section, the researchers first present the frequency distribution of responses of the whole group and then compared the perceptions of the two groups just mentioned. An independent t-test was used for the comparison of their mean score measuring perception. The five-point scale ranged from -2 (Disagreed) to 2 (Agreed).

\subsection{Impact Items}

Concerning the impact items, community/business leaders had positive, neutral, and negative opinions regarding the impact the four-day week had on the community businesses (see Table 1). The mean scores for these first three items are close to zero (range from -2 to 2 , with positive values indicating agreement); this indicates that on average, community members had neutral opinions or were evenly divided on the school district's four-day calendar model has had on their businesses and agencies. In item 1, responses were evenly distributed among agreeing, being neutral, and disagreeing with the statement that the four-day week had a positive impact on their business, agency, or employer. The responses were less positive about the profitability of such business (see Item 2). However, when it came to the four-day school week having a positive economic impact on the community as a whole, $44 \%$ of the respondents were neutral on the issue. 
Table 1. Frequency of Agreement and Mean of Impact Items $(n=71)$

\begin{tabular}{|c|c|c|c|c|c|c|}
\hline Impact Items & $\begin{array}{l}\% \\
\text { Agreed } \\
(2)\end{array}$ & $\begin{array}{l}\text { \% Somewhat } \\
\text { agreed } \\
\text { (1) }\end{array}$ & $\begin{array}{c}\% \\
\text { Neutral } \\
(0)\end{array}$ & $\begin{array}{l}\text { \% Somewhat } \\
\text { disagreed } \\
(-1)\end{array}$ & $\begin{array}{c}\% \\
\text { Disagreed } \\
(-2)\end{array}$ & Mean \\
\hline $\begin{array}{l}\text { 1. The four-day school week has had a } \\
\text { positive impact on my business, agency or } \\
\text { employer within the school district. }\end{array}$ & 20 & 10 & 33 & 7 & 29 & -0.14 \\
\hline $\begin{array}{l}\text { 2. The four-day school week has positively } \\
\text { impacted the profitability of my business or } \\
\text { employer in this community. }\end{array}$ & 11 & 11 & 35 & 9 & 34 & -0.45 \\
\hline $\begin{array}{l}\text { 3. The move to the four-day school week } \\
\text { has had a positive economic impact on this } \\
\text { community. }\end{array}$ & 16 & 10 & 44 & 7 & 23 & -0.11 \\
\hline
\end{tabular}

\subsection{School and Student Related Items}

Regarding the items related to the school and students, community/business leaders' responses were again positive, neutral, and negative (see Table 2). The mean scores for these six items are between -0.27 and 0.26 (range from -2 to 2 , with positive values indicating agreement); this indicates that on average, community members had neutral opinions or were evenly divided about the impact the school district's four-day model had on schools and students. In items 4, 8 , and 9, responses were slightly less favorable regarding the four-day week model. Thirty-eight percent of the respondents disagreed that the model improved public opinion of the quality of their school district. Items 7 and 9 are the most polarized items. Forty-seven percent of the respondents agreed they were concerned about the safety of the students during the weekday when they do not have school (see Item 7). At the same time, $43 \%$ of the respondents disagreed with this statement. Similarly, $44 \%$ of the respondents would like to see the school districts operating on a five-day school week, while $43 \%$ disagreed, with only $13 \%$ neutral (see Item 9 ).

Table 2. Frequency of Agreement and Mean of School and Students Items ( $n=71)$

\begin{tabular}{|c|c|c|c|c|c|c|}
\hline Impact Items & $\begin{array}{c}\% \\
\text { Agreed } \\
(2)\end{array}$ & $\begin{array}{l}\text { \% Somewhat } \\
\text { agreed } \\
(1)\end{array}$ & $\begin{array}{c}\% \\
\text { Neutral } \\
(0)\end{array}$ & $\begin{array}{l}\text { \% Somewhat } \\
\text { disagreed } \\
(-1)\end{array}$ & $\begin{array}{c}\% \\
\text { Disagreed } \\
(-2)\end{array}$ & Mean \\
\hline $\begin{array}{l}\text { 4. The four-day school week has improved } \\
\text { public opinion of the quality of our school } \\
\text { district. }\end{array}$ & 13 & 15 & 34 & 8 & 30 & -0.27 \\
\hline $\begin{array}{l}\text { 5. The four-day school week has improved } \\
\text { the academic quality of our school district. }\end{array}$ & 10 & 13 & 51 & 6 & 20 & -0.13 \\
\hline $\begin{array}{l}\text { 6. The four-day school week has lessened } \\
\text { the workload of teachers. }\end{array}$ & 19 & 20 & 43 & 6 & 12 & 0.26 \\
\hline $\begin{array}{l}\text { 7. On Mondays, when the schools are closed, } \\
\text { I am concerned about the safety of our } \\
\text { students. }\end{array}$ & 28 & 19 & 11 & 8 & 34 & 0 \\
\hline $\begin{array}{l}\text { 8. It would have been best to have waited } \\
\text { and prepared for an additional year before } \\
\text { moving to a four-day school week in our } \\
\text { school district. }\end{array}$ & 24 & 8 & 26 & 11 & 32 & -0.18 \\
\hline $\begin{array}{l}\text { 9. I would prefer our school district return to } \\
\text { a five-day school week. }\end{array}$ & 32 & 12 & 13 & 8 & 35 & -0.02 \\
\hline
\end{tabular}

Given that the items are either evenly distributed or polarized, responses from community/business leaders with and without children enrolled in the district were compared. A series of independent samples t-test were conducted on the community members' responses to see whether there was any significant different between the two groups.

Significant differences were found for items 2, 3, 5, 7, 8, and 9 (see Table 3). The perception of community members with children in the district was statistically different from those without enrolled children regarding: the four-day school week positively impacted the profitability of their business or employer $(t(63)=-2.38, \mathrm{p}<0.05)$; the four-day school week had a positive economic impact on the community $(t(68)=-2.12, \mathrm{p}<0.05)$; the four-day school week improved the academic quality of the school district $(t(67)=-2.24, \mathrm{p}<0.05)$; and when the schools are closed, being concerned about the safety of the students. $(t(65)=-2.15, \mathrm{p}<0.05)$. In all those cases, the perception of community/business leaders with children in school was slightly more favorable than that of members without children currently in school. Also, a statistical difference was found related to the return to a traditional five-day school week $(t(64)=-2.06, \mathrm{p}<0.05)$; community/business leaders without children in school agreed more than community members with children enrolled in the school district. Overall, community/business leaders with children currently enrolled in the school district preferred to remain on the new four-day 
school calendar while those community/business leader without children enrolled in school preferred to return to the five-day school week calendar.

Table 3. Descriptive Statistics and Group Comparison by Having Children

\begin{tabular}{|c|c|c|c|c|c|c|}
\hline & $\begin{array}{l}\text { Children in } \\
\text { the district }\end{array}$ & $\mathrm{n}$ & Mean & $\mathrm{sd}$ & $t$ & $d f$ \\
\hline \multirow{2}{*}{$\begin{array}{l}\text { 1. The four-day school week has had a positive impact on } \\
\text { my business, agency or employer within the school } \\
\text { district. }\end{array}$} & No & 43 & -.37 & 1.273 & \multirow[t]{2}{*}{-1.675} & \multirow[t]{2}{*}{67} \\
\hline & Yes & 26 & .23 & 1.704 & & \\
\hline \multirow{2}{*}{$\begin{array}{l}\text { 2. The four-day school week has positively impacted the } \\
\text { profitability of my business or employer in this } \\
\text { community. }\end{array}$} & No & 40 & -.75 & 1.127 & \multirow[t]{2}{*}{$-2.384^{*}$} & \multirow[t]{2}{*}{63} \\
\hline & Yes & 25 & .04 & 1.541 & & \\
\hline \multirow{2}{*}{$\begin{array}{l}\text { 3. The move to the four-day school week has had a positive } \\
\text { economic impact on this community. }\end{array}$} & No & 44 & -.36 & 1.102 & \multirow[t]{2}{*}{$-2.117^{*}$} & \multirow[t]{2}{*}{68} \\
\hline & Yes & 26 & .31 & 1.543 & & \\
\hline \multirow{2}{*}{$\begin{array}{l}\text { 4. The four-day school week has improved public opinion } \\
\text { of the quality of our school district. }\end{array}$} & No & 45 & -.44 & 1.216 & \multirow[t]{2}{*}{-1.439} & \multirow[t]{2}{*}{69} \\
\hline & Yes & 26 & .04 & 1.587 & & \\
\hline \multirow{2}{*}{$\begin{array}{l}\text { 5. The four-day school week has improved the academic } \\
\text { quality of our school district. }\end{array}$} & No & 43 & -.37 & .926 & \multirow[t]{2}{*}{$-2.238^{*}$} & \multirow[t]{2}{*}{67} \\
\hline & Yes & 26 & .27 & 1.458 & & \\
\hline \multirow{2}{*}{$\begin{array}{l}\text { 6. The four-day school week has lessened the workload of } \\
\text { teachers. }\end{array}$} & No & 41 & .15 & 1.131 & \multirow[t]{2}{*}{-1.010} & \multirow[t]{2}{*}{63} \\
\hline & Yes & 24 & .46 & 1.318 & & \\
\hline \multirow{2}{*}{$\begin{array}{l}\text { 7. On Mondays, when the schools are closed, I am } \\
\text { concerned about the safety of our students. }\end{array}$} & No & 41 & .34 & 1.652 & \multirow[t]{2}{*}{$2.147^{*}$} & \multirow[t]{2}{*}{65} \\
\hline & Yes & 26 & -.54 & 1.606 & & \\
\hline \multirow{2}{*}{$\begin{array}{l}\text { 8. It would have been best to have waited and prepared for } \\
\text { an additional year before moving to a four-day school } \\
\text { week in our school district. }\end{array}$} & No & 41 & .12 & 1.470 & \multirow[t]{2}{*}{$2.079^{*}$} & \multirow[t]{2}{*}{64} \\
\hline & Yes & 25 & -.68 & 1.600 & & \\
\hline \multirow{2}{*}{$\begin{array}{l}\text { 9. I would prefer our school district return to a five-day } \\
\text { school week. }\end{array}$} & No & 40 & .33 & 1.639 & \multirow[t]{2}{*}{$2.060^{*}$} & \multirow[t]{2}{*}{64} \\
\hline & Yes & 26 & -.54 & 1.702 & & \\
\hline
\end{tabular}

Note. $* p<.05$

\section{Discussion}

The three school districts that participated as part of this study are demographically similar and are located within sixty miles in neighboring counties of the same state. The unique nature of the four-day school week in the region of this study and the close proximity of the school districts participating in this research may have impacted the perspectives of the community/business leaders participating in this study. In addition, this study was a single data collection at the end of the first year of the four-day school week implementation which may alter the perspective of community/business leaders as compared to community/business leaders where the four-day school week had been implemented over a number of years. Two of the three communities participating in this study have a very limited number of businesses, therefore, greatly limiting the diversity of the data collection.

Within the context of rural communities, the local school district and the local business community are deeply intertwined. Not only do small rural school districts provide much needed jobs and revenue within a community, persons traveling to schools and school events provide much needed customers to small town businesses. When local school district decide to reduce the number of school days they will operate, the impact this move will have on local businesses is important to study. This research finds that from the perspective of local community/business leaders, the move to a four-day school week can be a polarizing decision. While looking at overall results, it initially appears that community/business leaders are neutral about the impact of the shorted school calendar on their businesses and their community. A deeper look reveals, however, that perceptions of the four-day calendar are polarized with community/business leaders falling strongly within the supportive or opposed positions with relatively few taking the neutral position on the topic when it relates to the impact on their own business.

When considering the economic impact of the switch to a four-day school calendar, $44 \%$ of community/business leaders were neutral when asked if the four-day calendar had had a positive impact on the community, and $22 \%$ felt the switch to the four-day calendar had had a positive economic impact on the profitability of businesses within a community. The most telling demonstration of the polarization of community/business leaders' perceptions is when asked if the school district should return to the five-day week school calendar, $44 \%$ of community/business leaders preferred a return to the traditional school calendar as compared to $43 \%$ who preferred to remain on the four-day week calendar. Only $13 \%$ of respondents were neutral when asked if the school should return to the traditional school calendar.

Maybe the most interesting finding for education and business leaders is the fact that this research shows that if community/business leaders had children enrolled in school they supported the four-day school calendar, while those that did not have children in school preferred to return to the traditional five-day calendar. This division is also found when 
asked about the impact the four-day calendar had on the profitability of their business and the economy of their community. Community/business leaders with children enrolled in school felt the shortened school calendar had had a positive impact on their business and the community while those without children in school did not.

\section{References}

Anderson, D. M., \& Walker, M. B. (2015). Does shortening the school week impact student performance? Evidence from the four-day school week. Education Finance and Policy, 10(3), 314-349. https://doi.org/10.1162/EDFP_a_00165

Ayala, E. (2017). Texas' rural schools need help attracting teachers, and it's all about the pay. Dallas News. Retrieved from https://www.dallasnews.com/news/education/2017/07/26/texas-rural-schools-need-help-attracting-teachers-pay

Baltes, B., Briggs, T., Huff, J., Wright, J., \& Neuman, G. (1999). Flexible and compressed workweek schedules: A meta-analysis of their effects on work-related criteria. Journal of Applied Psychology, 84(4), 496. https://doi.org/10.1037/0021-9010.84.4.496

Bitton, D. (2016, September 29). Morrison and Glencoe optimistic about four-day school week. Stillwater News Press. Retrieved http://www.stwnewspress.com/news/morrison-and-glencoe-optimistic-about-four-day-school-week/article_a0b6ac b9-77a8-52e0-bf63-6eec1545022c.html

Cooley, A. (2017, January 10). East Newton considers adopting four-day school week. The Joplin Globe, Retrieved from http://www.joplinglobe.com/news/local_news/east-newton-considers-adopting-four-day-school-week/article_4ad2 697d-696a-53e5-b3a2-62661e6b7e5c.html

Cummings, M. (2015, May 13). Adults love the four-day school week. Is it good for the kids? Slate. Retrieved October 25, 2016, http://www.slate.com/blogs/schooled/2015/05/13/the_four_day_school_week_is_it_good_for_the_kids.html

Cunningham. (1982). Compressed shift schedules: Altering the relationship between work and non-work. Public Administration Review, 42(5), 438-447. https://doi.org/10.2307/975646

Dam, A. (2006, July). The 4 day school week. Denver, Colorado: Colorado Department of Education.

DeNisco, A. (2013, November). More schools choose a four-day week. District Administrator. Retrieved December 30, 2016, from https://www.districtadministration.com/article/more-schools-choose-four-day-week

DenOuden, C. (2016, January 8). It's a 4-day week at some South Dakota schools. Grand Fork Herald. Retrieved from http://www.grandforksherald.com/news/education/3920131-its-4-day-week-some-south-dakota-schools

Donis, K. C., \& Silvernail, D. L. (2009, February). Research Brief: A review of the evidence on the four - day school week. Center for Education Policy, Applied Research and Evaluation, University of Southern Maine. Retrieved from https://usm.maine.edu/sites/default/files/cepare/Review_of_Evidence_on_Four-Day_School_Week.pdf

Facer II, R. L., \& Wadsworth, L. L. (2010). Four-day work weeks: Current research and practice. Connecticut Law Review, 42(4), 1031-1046.

Flexible and Compressed Work Schedules, 5 U.S.C. $\S \S 6122$. (1982).

French, J. (2017, August 31). Districts using 4-day weeks pass 50 percent. The Holyoke Enterprise. Retrieved from https://www.holyokeenterprise.com/school/districts-using-4-day-weeks-pass-50-percent

Griffith, M. (2011, May). What savings are produced by moving to a Four-Day school week? Moving to a shorter school week. Education Commission of the States. Retrieved from http://files.eric.ed.gov/fulltext/ED520160.pdf

Henton, D. M. (2015). The four-day school week. The School Administrator, 72(1), 28-32.

Herring, C. (2010, March). Schools' new math: The four-day week. The Wall Street Journal. Retrieved March 20, 2015, from http://www.wsj.com/articles/SB10001424052748704869304575104124088312524

Hinton, M. (2017, March 9). Are four-day school weeks the way of the future? Education Week, Retrieved from http://blogs.edweek.org/edweek/time_and_learning/2017/03/are_four-day_school_weeks_the_way_of_the_future. html

Hodge, B., \& Tellier, R. (1975). Employee reactions to the four-day week. California Management Review, 18(1), 25-30. https://doi.org/10.2307/41164622

Juneau, D. (2011, October). Four-Day School Week Report in Montana Public Schools. Helena, Montana: Montana Office of Public Instruction.

Kusmin, L. (2015). Rural America at a glance, 2015 edition. United States Department of Agriculture, Retrieved from https://www.ers.usda.gov/publications/pub-details/?pubid=44016 
Layton, L. (2011, October 28). In trimming school budgets, more officials turn to a four-day week. Washington Post. Retrieved from https://www.washingtonpost.com/local/education/in-trimming-school-budgets-more-officials-turn-to-a-four-day-w eek/2011/10/26/gIQABsiXQM_story.html?utm_term=.c039967c71a5

Leal, F. (2017, April 5). Outside the limelight, rural schools face challenges in finding, and keeping teachers. EdSource, Retrieved https://edsource.org/2017/outside-the-limelight-rural-schools-face-challenges-in-finding-and-keeping-teachers/579 426

Levin, K. (2016, September 4). More districts experimenting with four-day school week. The Joplin Globe. Retrieved October 17, 2016, from http://www.joplinglobe.com/news/local_news/more-districts-experimenting-with-four-day-school-week/article_6a dda892-725e-11e6-b182-bfc2430abf9d.html

Lyson, T. (2002). What does a school mean to a community? Assessing the social and economic benefits of schools to rural villages in New York. Journal of Research in Rural Education, 17(3), 131-137.

Missouri Department of Elementary and Secondary Education. (2013). Department of elementary and secondary education school finance. $\quad$ Retrieved from https://dese.mo.gov/sites/default/files/sf-BSchoolCalendarRequirements.pdf

Missouri Department of Elementary and Secondary Education. (2018). Missouri comprehensive data system - district and school information-History of the 4 day week. Retrieved January 19, 2018.

Morones, A. (2013, September 18). Iowa district reimagines the five-day school week. Education Week, 33(4), 10-11.

Newman, Z., Pavolva, U., \& Luna, C. (2016, March 10). Many Missouri school districts cite benefits of four-day weeks. KOMU News. Retrieved December 26, 2016, from http://www.komu.com/news/many-missouri-school-districts-cite-benefits-of-four-day-weeks

Plucker, J. A., Cierniak, K., \& Chamberlin, M. (2012). The four-day school week: Nine years later. Center for Evaluation and Education Policy, 10(6), 1-8.

Ray, J. (2003, September 16). Americans resist idea of four-day school week. Gallup. Retrieved December 30, 2016, from, http://www.gallup.com/poll/9256/americans-resist-idea-fourday-school-week.aspx

Richert, K. (2016, May 10). What do the numbers say about four-day school weeks? Idaho Education News. Retrieved from http://www.edweek.org/ew/articles/2015/12/15/what-do-the-numbers-say-about-four-day.html

Rosenberg, M. (2015, January). What math says about four-day week savings. School Administrator, 72(1), 30-31.

Rowland, J. (2014, October). Number of instructional days/hours in the school year. Retrieved from http://www.ecs.org/ec-content/uploads/Number-of-Instructional-Days-Hours-in-a-School-Year_Revised.pdf

Sagness, R. L., \& Salzman, S. A. (1993, October). Evaluation of the four-day school week in Idaho suburban schools. Jackson, WY. Retrieved from http://files.eric.ed.gov/fulltext/ED362995.pdf

School Operations, 171, Four-day school week authorized--calendar to be filed with department, $\$ \$ 171.029-171.031$, (2009).

Sederberg, C. H. (1987). Economic role of school districts in rural communities. Research in Rural Education, 4(3), 125-130.

Stotts, M. (2017, February 15). MPS considering four-day school week. The Miami News-Record, Retrieved from http://www.miamiok.com/news/20170215/mps-considering-four-day-school-week

Tobias, S. P. (2016, April 19). Southeast Kansas district implements four-day school week. The Wichita Eagle. Retrieved from http://www.kansas.com/news/local/education/article72631157.html

Woods, M. D., Doeksen, G. A., \& Clair, C. S. (2005). Measuring local economic impacts of the education sector. Education, Human Capital and the Local Economy, 16-21. Retrieved from $\mathrm{http} / / /$ srdc.msstate.edu/publications/archive/235.pdf\#page=16

\section{Copyrights}

Copyright for this article is retained by the author(s), with first publication rights granted to the journal.

This is an open-access article distributed under the terms and conditions of the Creative Commons Attribution license which permits unrestricted use, distribution, and reproduction in any medium, provided the original work is properly cited. 